Transformasi : Jurnal Pendidikan Matematika dan Matematika

Volume 4, No. 1, Bulan Juni Tahun 2020, pp. 219-236

ISSN 2549-1164 (online)

Available online at https:/ / ejournal.unibabwi.ac.id/ index.php/ transformasi

\title{
ANALISIS KESALAHAN SISWA DALAM MENYELESAIKAN SOAL HOTS BERDASARKAN KEMAMPUAN PENALARAN MATEMATIS
}

\author{
Dinda Amalia ${ }^{1}$,Windia Hadi ${ }^{2}$ \\ 1,2 Fakultas Keguruan dan Ilmu Pendidikan, Universitas Muhammadiyah \\ Prof. DR. HAMKA \\ Email korespondensi : windia.hadi@uhamka.ac.id
}

Diterima : 16-05-2020, Revisi: 09-06-2020, Diterbitkan : 26-06-2020

\begin{abstract}
ABSTRAK
Penelitian ini bertujuan untuk mendeskripsikan faktor penyebab kesalahan yang dilakukan siswa yang mempunyai kemampuan penalaran tinggi dan rendah dalam menyelesaikan soal HOTS berdasarkan teori Newman. Jenis penelitian ini adalah deskriptif kualitatif. Subjek penelitian berjumlah 36 siswa kelas VIII di salah satu SMP Jakarta semester ganjil tahun ajaran 2019/2020 untuk menentukan kategori kemampuan penalaran matematis. Teknik pengumpulan data menggunakan tes dan wawancara. Kerangka analisis dikembangkan berdasarkan kategori kesalahan Newman. Hasil penelitian menunjukkan siswa kemampuan penalaran tinggi matematis (SKPT) memiliki kesalahan dalam memahami soal dan kesalahan keterampilan proses serta mampu menyelesaikan soal HOTS dengan benar tanpa ada kesalahan, sedangkan siswa kemampuan penalaran rendah (SKPR) rendah memiliki kesalahan memahami soal HOTS dan kesalahan dalam keterampilan proses. Faktor yang menyebabkan kesalahan SKPT adalah kekeliruan dalam melakukan perhitungan dalam menyelesaikan soal HOTS sedangkan, faktor penyebab kesalahan SKPR adalah pada segi kognitif yaitu kurang memahami soal dengan baik.
\end{abstract}

Kata kunci : Analisis Kesalahan Newman, High-Order Thinking Skills (HOTS), Kemampuan Penalaran Matematis 


\begin{abstract}
This study aims to describe the factors that cause errors made by students who have high and low reasoning abilities in solving HOTS problems based on Newman's theory. This type of research is descriptive qualitative. The research subjects consisted of 36 VIII grade students in one of Jakarta's junior high schools in the odd semester of the 2019/2020 school year to determine the category of mathematical reasoning abilities. Data collection techniques using tests and interviews. The analytical framework was developed based on the Newman error category. The results showed that students with high mathematical reasoning ability (SKPT) had errors in understanding questions and process skill errors and were able to solve HOTS questions correctly without any errors, while students with low reasoning ability (SKPR) had errors in understanding HOTS questions and errors in process skills . Factors that cause SKPT errors are errors in calculating the HOTS problem while, the factors that cause SKPR errors are on the cognitive side of not understanding the good questions.
\end{abstract}

Keywords : Newman's Eror Analysis, High-Order Thinking Skills (HOTS), Reasoning Mathematics Ability.

\title{
Pendahuluan
}

Isu yang banyak dibincangkan akhir-akhir ini adalah kemampuan berpikir tingkat tinggi atau yang biasa dikenal dengan HOTS. HOTS termasuk dalam kategori aspek kognitif pada Taksonomi Bloom yaitu pada level analisis, sintesis dan mencipta (Munzenmaier \& Rubin, 2013). Taksonomi Bloom menggambarkan proses berpikir siswa. Pemikiran tingkat tinggi terjadi ketika siswa mendapatkan pengetahuan baru dan menyimpannya dalam memori, maka pengetahuan ini berkorelasi dengan pengetahuan sebelumnya untuk mencapai tujuan tertentu (Abosalem, 2016). Pada pemikiran tingkat tinggi, siswa akan cenderung untuk menggunakan logika daripada hanya mengingat dan menghafal rumus, sehingga siswa akan menguasai konsep-konsep dan dapat memecahkan masalah matematika yang lebih kompleks (Nurina \& Retnawati, 2015; Jailani, Sugiman, \& Apino, 2017).

Karakteristik HOTS adalah (Retnawati, Kartowagiran, Arlinwibowo, \& Sulistyaningsih, 2017): (a) non-algoritmik, (b) kompleks; (c) menghasilkan banyak solusi; (d) melibatkan perbedaan pendapat atau interpretasi; (e) melibatkan penerapan berbagai kriteria; (e) melibatkan ketidakpastian; (f) menuntut kemandirian dalam proses berpikir; $(\mathrm{g})$ melibatkan makna yang mengesankan; (h) membutuhkan kerja keras (upaya). Keterampilan berpikir yang dapat dikategorikan sebagai HOTS adalah : (1) sebagai bentuk transfer hasil belajar; (2) sebagai bentuk berpi- 
kir kritis; dan (3) sebagai proses pemecahan masalah (Brookhart, 2010; Ramos, Dolipas, \& Villamor, 2013). Sedangkan ciri-ciri HOTS meliputi kemampuan berpikir kritis dan kreatif (Barak, David, \& Uri, 2007; Wang \& Wang, 2011; Conklin, 2012; Ramos, Dolipas, \& Villamor, 2013; Tanujaya, Mumu, Margono, 2017; Hassan, Rosli, \& Zakaria, 2016). Dengan demikian, dapat diambil irisan bahwa keterampilan berpikir yang dikategorikan sebagai HOTS adalah pemecahan masalah dan penalaran. Berpikir tingkat tinggi merupakan analisis tentang memahami pertanyaan atau informasi baru dengan menggunakan dan menerapkan pengalaman sebelumnya, untuk memperoleh suatu jawaban dalam situasi yang sulit dan tercapainya suatu tujuan (Yang, 2015; Heong et al., 2012).

Di Indonesia kemampuan berpikir tingkat tinggi pada matematika dapat dikatakan masih rendah. Hal ini terbukti dari hasil penelitian Wibowo, Pamujiarso \& Rini (2016) yang menyatakan bahwa siswa belum memiliki kemampuan dalam menyelesaikan soal yang dituntut untuk berpikir tingkat tinggi. Salah satu penyebabnya adalah siswa tidak terbiasa menyelesaikan soal pada tingkat tinggi atau HOTS. Akibatnya banyak kesalahan yang dilakukan siswa dalam menyelesaikan soal HOTS. Terkait dengan hasil Ujian Nasional dan hasil penilaian TIMSS siswa Indonesia, ada beberapa faktor yang mempengaruhi rendahnya persentase siswa Indonesia dalam penilaian internasional, yaitu siswa Indonesia tidak terbiasa menjawab pertanyaan yang membutuhkan pembenaran untuk menjawabnya (Johar, Yusniarti, \& Saminan, 2018).

Banyak sudah enelitian yang membahas tentang kesalahan siswa dalam menyelesaikan soal HOTS diantaranya adalah kesalahan dalam menyelesaikan soal bentuk aljabar, tipe HOTS (Agustina \& Khotimah, 2018), analisis kesalahan siswa dalam menyelesaikan trigonometri tipe HOTS ditinjau dari gender (Mulyani \& Muhtadi, 2019), analisis kesalahan siswa dalam menyelesaikan soal HOTS matematika (Permana, 2019), analisis kesalahan representasi simbolik mahasiswa dalam menyelesaikan soal HOTS (Aliyanti, Putri, \& Zukhrufurrohmah, 2019) yang semua menggunakan teori Newman. Terdapat 5 aspek dalam menyelesaikan suatu masalah berdasarkan teori Newman agar terhindar dari kesalahan yaitu : membaca masalah, memahami masalah, transformasi, proses keterampilan, dan penulisan jawaban akhir (enconding) (Newman, 1977 ; Oktavia, 2018)

Pada penelitian sebelumnya lebih sering dibahas kesalahan dalam mengerjakan soal khususnya dalam materi aljabar, trigonometri dan soal matematika lainnya. Namun belum ada penelitian yang menitikberatkan pada kemampuan penalaran 
matematis. Jika siswa sudah mempunyai kemampuan penalaran matematis yang baik maka dapat dikatakan siswa mampu dalam memahami matematika yaitu menyelesaikan soal HOTS (Hadi, 2016). Setiap masalah matematika membutuhkan keterampilan penalaran, dan keterampilan penalaran siswa dapat dilatih dengan mengajukan pertanyaan yang dirancang secara terstruktur sehingga siswa terbiasa dalam menjawab pertanyaan/menyelesaikan masalah (Rizky \& Surya, 2017). Tujuan penelitian ini adalah untuk mendeskripsikan faktor kesalahan siswa dalam menyelesaikan soal HOTS berdasarkan kemampuan penalaran matematis siswa, dengan kategori kemampuan penalaran tinggi dan kemampuan penalaran rendah.

\section{Metode Penelitian}

Metode penelitian ini adalah penelitian deskriptif kualitatif, artinya penelitian ini bertujuan untuk menganalisis dan mendeskripsikan gambaran mengenai kesalahan siswa dalam menyelesaikan soal HOTS berdasarkan kemampuan penalaran matematis. Sampel penelitian adalah 36 siswa kelas VIII SMP di Jakarta semester ganjil tahun pelajaran 2019/2020. Pengumpulan data pada penelitian ini dilihat dari hasil tes soal HOTS berdasarkan indikator kemampuan penalaran matematis.

Untuk menganalisis kesalahan siswa dalam menyelesaikan soal HOTS berdasarkan kemampuan penalaran matematis, diberikan tes esai terdiri dari 5 soal dengan indikator : (1) memberikan penjelasan dengan menggunakan model, fakta, sifat dan hubungan; (2) menggunakan pola dan hubungan untuk menganalisis situasi matematika, menarik anologi dan generalisasi; (3) memperkirakan jawaban dan proses solusi; (4) justifikasi/ pembuktian; (5) menarik kesimpulan yang logis. Tes kemampuan penalaran matematis sudah divalidasi oleh dua orang ahli, yaitu dosen dan guru matematika. Kedua validator menyatakan bahwa tes kemampuan penalaran sesuai untuk digunakan dengan beberapa revisi terkait bahasa. Untuk mengetahui kesalahan-kesalahan yang dilakukan siswa, data yang diperoleh dianalisis berdasarkan pedoman kesalahan Newman dengan indikator-indikator (Mulyani \& Muhtadi, 2019) seperti disajikan pada Tabel 1 berikut.

Tabel 1. Indikator Kesalahan Siswa Berdasarkan Prosedur Analisis Newman

\begin{tabular}{|c|c|c|}
\hline No & Analisis Kesalahan Newman & Indikator Kesalahan \\
\hline 1. & Membaca (Reading) & $\begin{array}{l}\text { - Tidak dapat membaca/mengartikan ka- } \\
\text { ta-kata yang dianggap sulit yang diajukan }\end{array}$ \\
\hline 2. & Memahami (Comprehension) & $\begin{array}{l}\text { - Tidak menuliskan apa yang diketahui dan } \\
\text { tidak dapat menjelaskan secara tersirat dari } \\
\text { soal }\end{array}$ \\
\hline
\end{tabular}


- Tidak menuliskan apa yang ditanyakan dan tidak dapat menjelaskan maksud dari pertanyaan soal

- Menuliskan apa yang diketahui dengan simbol-simbol yang dibuat sendiri dan tanpa keterangan

- Menuliskan hal yang ditanyakan secara singkat sehingga tidak jelas

- Menuliskan hal yang ditanyakan tidak sesuai dengan yang diminta di soal

3. Transformasi (Transformation)

- Tidak mengubah informasi pada soal ke dalam kalimat matematika dan tidak dapat menjelaskan proses perubahannya

- Mengubah informasi pada soal ke dalam kalimat matematika tapi tidak tepat

$\begin{array}{llll}\text { 4. Keterampilan Proses (Process } & \text { - } & \text { Kesalahan dalam komputasi } \\ & \text { - Skill) } & \text { Tidak dapat menjelaskan proses komputasi } \\ & & \text { dalam lembar jawaban } \\ & & \text { - Tidak melanjutkan prosedur penyelesaian } \\ & & \text { (macet) } \\ & & \text { - Tidak menuliskan jawaban } \\ & \text { - } & \text { Menuliskan jawaban yang tidak tepat } \\ & \text { - } & \text { Menuliskan jawaban yang tidak sesuai den- } \\ & & \text { gan konteks soal } \\ & \text { - Tidak menyertakan satuan yang sesuai }\end{array}$

Wawancara dilakukan dengan 3 perwakilan siswa yang mempunyai kemampuan penalaran tinggi dan rendah berdasarkan indikator yang diperoleh siswa dalam mengerjakan soal HOTS sesuai kemampuan penalaran matematis. Kemampuan untuk mengurutkan didasarkan pada hasil skor rata-rata dan standar deviasi siswa dalam mengerjakan soal HOTS berdasarkan kemampuan penalaran matematis. Siswa dengan skor diatas rata-rata dikategorikan kedalam kemampuan penalaran tinggi dan siswa dengan skor dibawah rata-rata dikategorikan kedalam kemampuan penalaran rendah. Kemudian ketiga siswa diberikan tes kedua yang bertujuan untuk melihat konsistensi jawaban siswa. Hasil tes dianalisis sesuai kesalahan yang terjadi pada jawaban siswa. 


\section{Hasil dan Pembahasan}

Penelitian ini membahas tentang kesalahan siswa dalam menyelesaikan soal HOTS berdasarkan kemampuan penalaran matematis. Data dalam penelitian ini diperoleh dari hasil tes tertulis dan wawancara dengan siswa. Proses analisis data dengan menggunakan peta variabel tabel WinSteps, yang bertujuan untuk melihat kategori kemampuan penalaran tinggi dan rendah siswa serta kesulitan item soal (indikator kemampuan penalaran matematis).

Gambar 1 menunjukkan hasil kategori kemampuan penalaran matematis pada soal HOTS.

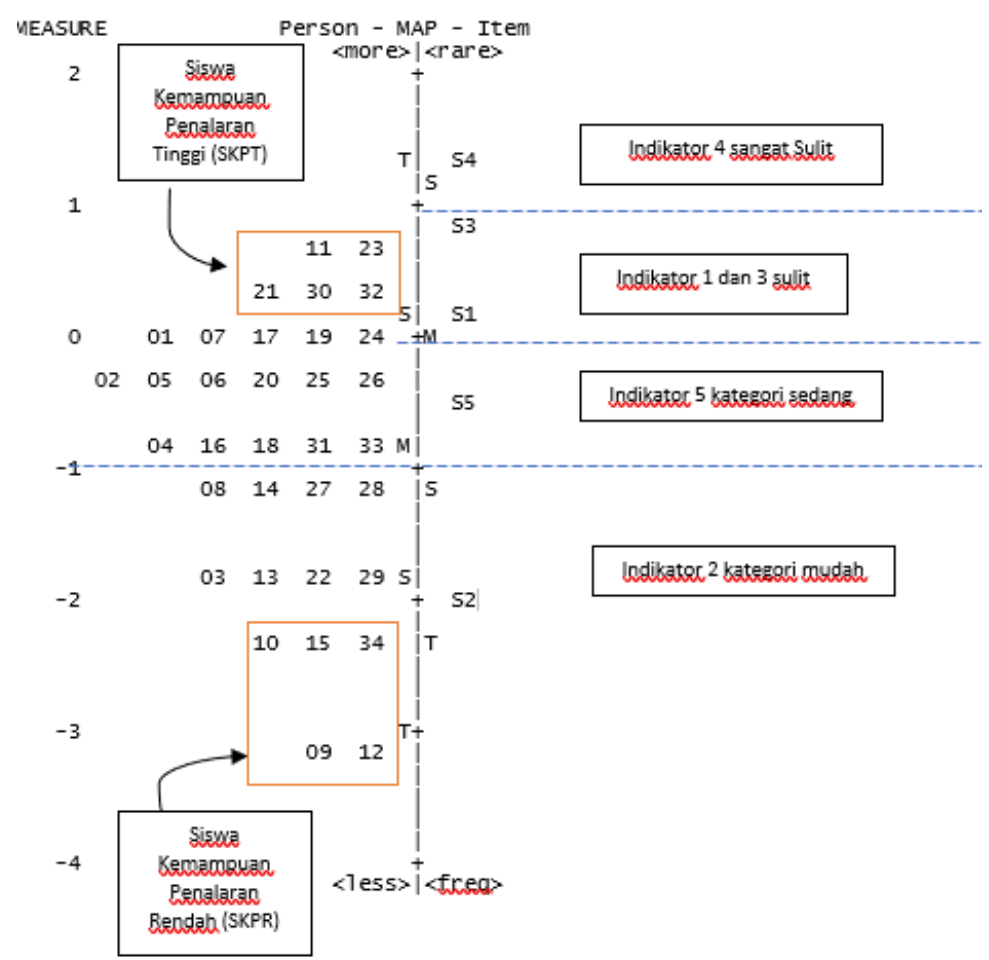

Gambar 1. Variabel Maps Kemampuan Penalaran Matematis

Berdasarkan hasil analisis data pada gambar 1 didapat bahwa siswa dengan kode nomor 11, 23, 21, 30 dan 32 mempunyai kemampuan penalaran tinggi dalam menyelesaikan soal HOTS, sedangkan kode siswa 09, 12, 10, 15, dan 34 mempunyai kemampuan penalaran rendah dalam menyelesaikan soal HOTS. Item soal HOTS yang dikategorikan mudah sampai dengan sulit yaitu item indikator 2, 5, 1, 3 dan 4 . Artinya bahwa indikator soal 4 memiliki tingkat kesulitan yang tinggi dibandingkan dengan indikator item yang lain. Selanjutnya di bawah ini akan dipaparkan hasil ke- 
salahan siswa kemampuan penalaran tinggi dan rendah dalam menyelesaikan soal HOTS.

\section{Paparan Hasil Kesalahan siswa berdasarkan kemampuan penalaran tinggi (SKPT)}

Kemampuan penalaran matematis tinggi siswa dalam menyelesaikan soal HOTS dipilih random yaitu kode 21 dengan inisial nama (MT). Berdasarkan hasil jawaban yang dikerjakan oleh MT, MT mampu menyelesaikan semua item semua soal kecuali item indikator 4 yaitu justifikasi/pembuktian.

Item indikator soal pertama adalah memberikan penjelasan dengan menggunakan model, fakta, sifat dan hubungan. Di bawah ini merupakan hasil wawancara Peneliti (P) dengan MT.

$\mathrm{P} \quad$ : "Dari nomor 1 informasi apa saja yang anda dapatkan?"

MT : "Informasi yang saya dapatkan, terdapat ketiga lingkaran kecil dengan masing-masing jari-jarinya yaitu $15 \mathrm{~cm}$, setiap lingkaran itu bersinggungan, lalu terdapat persegi panjang dan lingkaran besar"

P : "Dapatkah anda menjelaskan langkah-langkah dalam menyelesaian masalah ini?"

MT : "Pertama-tama saya mencari nilai dari jari-jari lingkaran besar. Sebelum saya mendapatkan nilai dari jari-jari lingkaran besar, terlebih dahulu saya mencari diameter lingkaran besar dengan menggunakan informasi yang diketahui pada soal yaitu jari-jari lingkaran kecil adalah $15 \mathrm{~cm}$, sehingga diameter lingkaran besar membutuhkan 6 jari-jari lingkaran kecil, kemudian $15 \times 6=90 \mathrm{~cm}$. Sehingga diperoleh diameter lingkaran besar adalah $90 \mathrm{~cm}$ "

P : : "Lalu setelah itu?"

MT : "Untuk mendapatkan jari-jari lingkaran besar, dengan diameter adalah setengahnya dari jari-jari, maka $90 / 2=45 \mathrm{~cm}$. Didapat bahwa jari-jari lingkaran besar adalah $45 \mathrm{~cm} "$

P : "Apakah menurut anda itu merupakan jawaban yang benar?"

MT : "Menurut saya, iya bu."

P : : "Lalu setelah itu?"

MT : "Setelah saya mendapatkan nilai dari jari-jari lingkaran besar, maka sayamemperoleh luas dari lingkaran besar itu sendiri, yaitu $6358,50 \mathrm{~cm}$ "

P : : "Bagaimana dengan persegi panjang ?"

MT : "Untuk mendapatkan panjang dari persegi panjang dilihat dari diameter lingkaran besar yaitu $90 \mathrm{~cm}$, dan lebar dari persegi panjang dilihat dari diameter lingkaran kecil yaitu $30 \mathrm{~cm}$. Sehingga diperoleh luas dari persegi panjang adalah $2700 \mathrm{~cm} . "$

P : "Lalu setelah itu?" 
MT : "Mendapatkan luas lingkaran besar tanpa persegi, maka 6358,50-2700= 3658,5 cm."

Subjek dengan kemampuan penalaran tinggi yaitu MT mampu menjelaskan dengan baik cara menyelesaikan soal HOTS, hasil penjelasan sesuai dengan hasil lembar jawaban MT, hal ini menunjukkan MT mampu memberikan penjelasan dengan menggunakan model, fakta dan hubungannya. Namun ketidaktelitian MT dalam menghitung menyebabkan salah dalam menyelesaikan soal HOTS. Gambar 2. merupakan hasil solusi atau penyelesaian MT dalam memahami item indikator pertama.

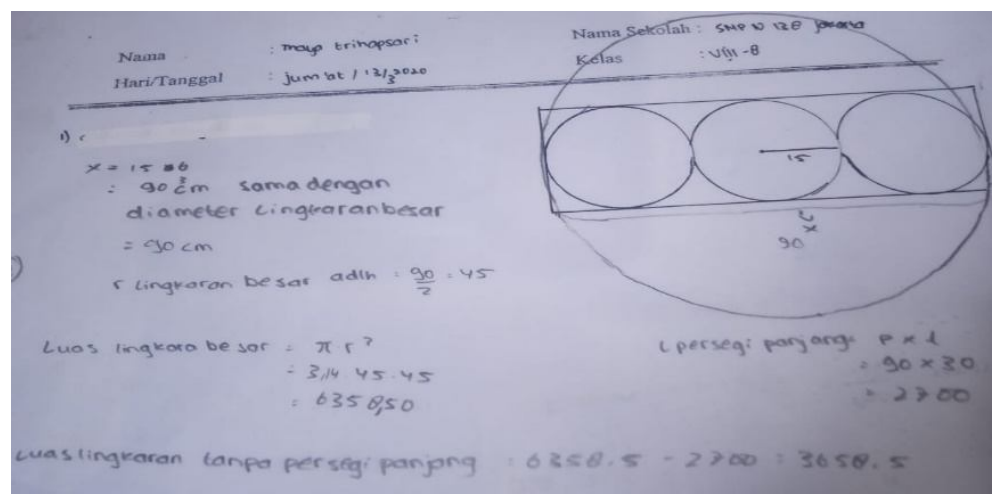

Gambar 2. Kesalahan Keterampilan Proses pada indikator 1

Berdasarkan hasil wawancara dan kecocokan dengan lembar jawaban, MT dapat membaca soal dengan baik, memahami dan mengetahui informasi atau perincian masalah yang diberikan pada soal HOTS, dan mentransformasi ke dalam bentuk kalimat matematika yaitu dengan menggunakan symbol matematika, namun dalam keterampilan proses MT salah dalam melakukan komputasi sehingga menyebabkan tidak dapat menyelesaikan indikator 1. MT salah dalam mengilustrasikan informasi pada soal, menyebabkan beberapa hal dinyatakan salah, sehingga, akhir dari penyelesaian masalah dinyatakan salah. Faktor kesalahan yang dialami oleh siswa yaitu keliru dalamm menjawab. Menurut Gais \& Afriansyah (2017) banyak faktor yang menyebabkan siswa masih keliru dalam mengerjakan soal-soal HOTS, yaitu proses yang dilewati saat pembelajaran tidak optimal, kurangnya pemahaman soal, ketidaklengkapan dalam membaca pertanyaan dan tidak menyerap pengetahuan dengan baik, tidak memahami transformasi masalah, tidak mengikuti materi secara menyeluruh, dan pemahaman mengenai konsep matematis yang lemah (Rohmah \& Sutiarso, 2018).

Item indikator soal kedua adalah menggunakan pola dan hubungan untuk menganalisis situasi matematika, menarik anologi dan generalisasi. Di bawah ini merupakan hasil wawancara peneliti (P) dengan MT.

$\mathrm{P} \quad$ : “Dari nomor 2 informasi apa saja yang anda dapatkan?" 
MT : "Informasi yang saya dapatkan, terdapat pengulangan huruf, dimana pengulangan berada disetiap 13 huruf, 13 huruf akan berulang huruf yang sama dari awal hingga akhir secara berulang-ulang"

P : :Apa yang ditanya dalan masalah ini?"

MT : "untuk yang A apa huruf ke 2020, dan B apabila banyaknya hurif sebanyak n maka tentukan polanya"

P : : "Dapatkah anda menjelaskan langkah-langkah dalam menyelesaian masalah ini?"

MT : "Langkah pertama yang saya lakukan dalam mengisi pertanyaan A adalah mebagi 2020 dengan banyaknya huruf (13) sehingga yang diperoleh adalah 155 dengan memiliki sisa 5, dengan begitu huruf ke 5 adalah O, sehingga huruf ke 2020 adalah O"

$\mathrm{P} \quad$ : "Bagaimana dengan yang B"?

MT : "Langkah pertama yang saya lakukan dalam mengisi pertanyaan B adalah, pola itu dilambangkan dengan $n$ maka dibagi dengan banyaknya huruf yaitu 13 sebelum diberulang-ulang"

P : : “Kesulitan apa yang kamu hadapi dalam menyelesaikan masalah ini?”

MT : "Kesulitan nya dalam memahami mengenai soal yang diberikan"

P : : "Kesimpulan apa yang anda peroleh dari masalah ini?"

MT : "Apabila soal tersebut merupakan suatu pola, langkah awal yang harus kita ketahui adalah berapa kalo pengulangan pola dalam soal tersebut"

Berdasarkan hasil wawancara MT mampu menguasai indikator menggunakan pola dan hubungan untuk menganalisis situasi matematika, menarik anologi dan generalisasi dengan baik. Gambar 3 merupakan hasil solusi atau peyelesaian pada siswa MT dalam menyelesaikan soal HOTS.

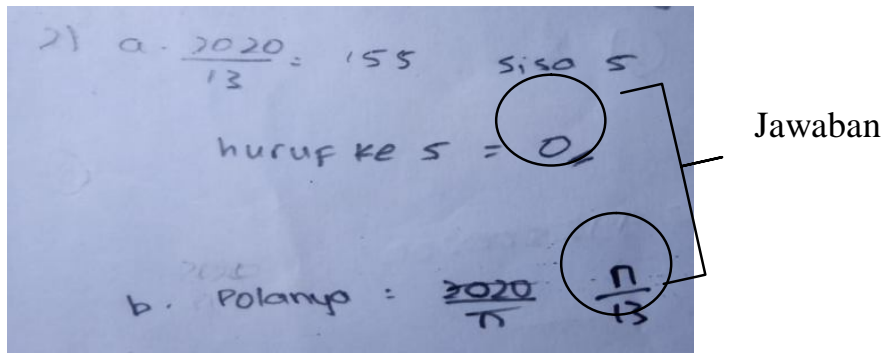

Gambar 3. Hasil Jawaban Benar Indikator Kedua

Berdasarkan hasil wawancara yang ditemukan MT dalam menentukan hasil akhir, langkah-langkah yang dilakukan MT dikategorikan benar dalam menjawab bagian a dan b, sehingga MT sudah mampu menyelesaikan indikator kedua dengan baik. Tidak ada kesalahan dalam menjawab soal HOTS.

Item indikator ketiga adalah memperkirakan jawaban dan proses solusi. Di bawah ini merupakan hasil wawancara peneliti (P) dengan MT. 
$\mathrm{P} \quad$ : "Dari nomor 3 informasi apa saja yang anda dapatkan?"

MT : "Informasi yang saya dapatkan, yaitu suatu bilangan ABCD apabila dijumlahka akan menghasilkan 10, BCD, akan habis dibagi 3, angka stauannya adalah $\frac{1}{4}$ angka yang berada didepannya, dan jumlah angka ratusan dan puluhan adalah angka satuan"

$\mathrm{P} \quad$ : “Apa yang ditanya dalan masalah ini?"

MT : "berapa angka pada ABCD"

$\mathrm{P} \quad$ : “Dapatkah anda menjelaskan langkah-langkah dalam menyelesaian masalah ini?"

MT : "Langkah pertama yang saya lakukan yaitu dengan menentukan angka berapa saja yang ada pada huruf $\mathrm{ABCD}$, setelah menentukan apakah angka itu sesuai tidak apabila dijumlahkan 10, huruf BCD habis dibagi 3 dan apakah DC adalah $\frac{1}{4}$ angka yang berada didepannya, dengan begitu baru saya bisa menentukan apa saja angka ABCD"

$\mathrm{P} \quad$ : "Menurut kamu apakah langkah yang kamu gunakan sudah benar?"

MT : "Iya bu"

P : : "Kesulitan apa yang kamu hadapi dalam menyelesaikan masalah ini?"

MT : "Kesulitan nya dalam kalimat pada soal, dan terlalu banyak angka yang mengakibatkan saya sulit memahami soalnya bu"

P $\quad$ : "Kesimpulan apa yang anda peroleh dari masalah ini?"

MT : "Kesimpulannya angka yang saya dapatkan adalah dari ABCD yaitu 1234"

Berdasarkan hasil wawancara MT memahami dengan baik soalnya sehingga mampu menguraikan Langkah-langkah dalam menyelesaikannya. MT mampu dalam indikator memperkirakan jawaban dan menjabarkan proses solusinya. Gambar 4 merupakan hasil solusi atau penyelesaian pada siswa MT dalam menyelesaikan soal HOTS.

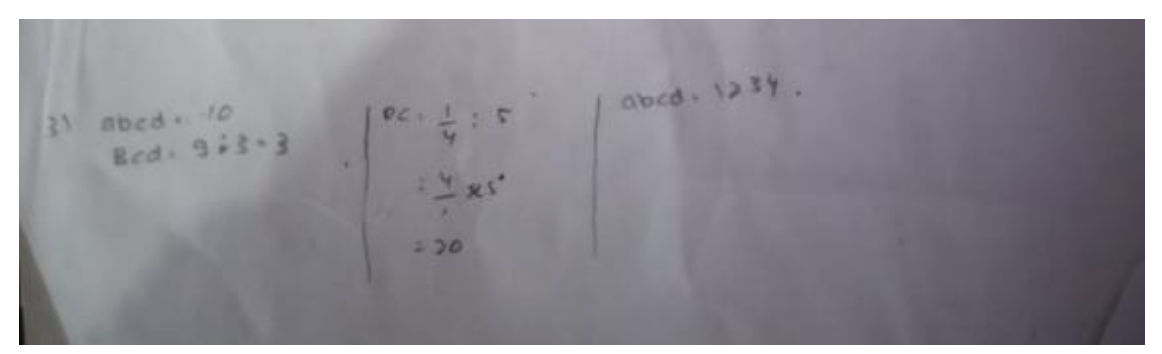

Gambar 4. Kesalahan Keterampilan Proses pada Indikator Ketiga

Berdasarkan hasil wawancara yang ditemukan MT dalam menentukan hasil akhir, MT dapat membaca soal dengan baik, selanjutnya MT memahami maksud dari soal, MT memahami apa yang ditanyakan dan diketahui dalam soal, setelah itu MT mampu menjelaskan Langkah pengerjaan dengan baik ditandai dengan adanya transfor- 
masi ke dalam bentuk kalimat matematika, namun MT tidak dapat menyelesaikan proses dengan baik sehingga menyebabkan salah dalam perhitungan. Faktor yang menyebabkan MT sulit dalam menyelesaikan soal HOTS adalah soal terlalu banyak angka sehingga membuat MT susah dalam memahami soal yang dimaksud. Sehingga kesalahan MT yaitu dalam keterampilan proses menyelesaikan soal HOTS. Hal inI sesuai dengan hasil penelitian Mu'minah (2018) yang menunjukkan bahwa siswa melakukan kesalahan dalam menafsirkan masalah matematika, gagal merencanakan strategi sehingga menyebabkan kesalahan dalam memilih operasi hitung dan berdampak pada gagalnya menyelesaikan jawaban.

Item indikator keempat adalah justifikasi/ pembuktian. Di bawah ini merupakan hasil wawancara peneliti (P) dengan MT.

$\mathrm{P} \quad$ : "Dari nomor 4 informasi apa saja yang anda dapatkan?"

MT : "Informasi yang saya dapatkan adlah bahwa panjang $\mathrm{AB}=\mathrm{BA}, \mathrm{BC}=\mathrm{CB}$, dam $\mathrm{DC}=$ $\mathrm{CD}$, tetapi dari informasi itu saya belum bisa mengetahui langkah apa saja yang harus saya lakukan untuk menyelesaikan soal tersebut"

P : : "Lalu bagaimana kamu bisa mendapatkan jawaban ini?"

MT : "Asal-asalan bu"

P : : "Menurut kamu apakah langkah yang kamu gunakan sudah benar?'

MT : "Tidak bu"

P : : "Kesulitan apa yang kamu hadapi dalam menyelesaikan masalah ini?"

MT : "Kesulitan nya, dari awal saya melihat gambarnya saya sudah kesulitan dalam menjawabnya bu"

Berdasarkan hasil wawancara, MT tidak yakin dengan jawabannya dan dia ragu dalam menyelesaikannya karena tidak mengetahui tahap penyelesaian selanjutnya. Gambar 5 merupakan hasil solusi atau peyelesaian pada siswa MT dalam menyelesaikan soal HOTS.

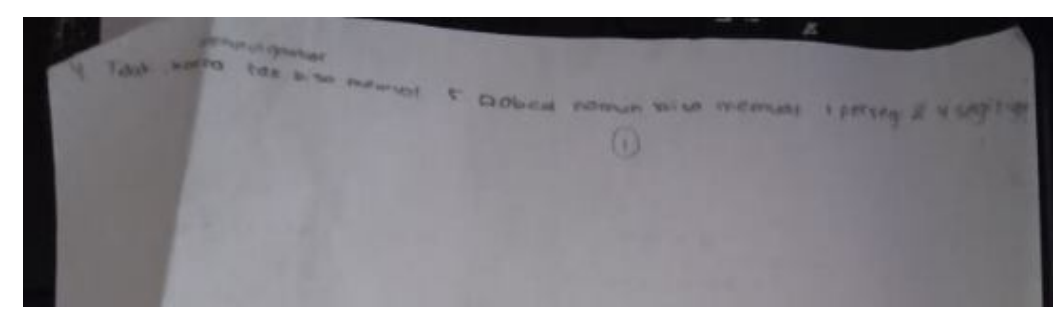

Gambar 5. Kesalahan dalam memahami soal pada Indikator keempat

Berdasarkan hasil jawaban MT dan wawancara, MT tidak mampu menyelesaikan soal HOTS indikator keempat. MT dapat membaca informasi soal, namun MT tidak memahami maksud dari gambar yang telah diberikan dalam soal HOTS. Sehingga menyebabkan kesalahan dalam memahami gambar yaitu tidak menuliskan apa yang 
diketahui dalam informasi soal yang diberikan. Indikator keempat memang item sangat sulit sehingga MT yang memiliki kemampuan penalaran tinggi tidak mampu dalam menyelesaikan soal HOTS. Ketidakpahaman dalam memahami gambar merupakan kendala atau kesulitan dalam menjawabnya. Sesuai dengan hasil penelitian Arumiseh, Hartoyo, \& Bistari (2019) yang menunjukkan bahwa faktor penyebab kesalahan siswa terletak pada segi kognitifnya diantaranya yaitu siswa kebingungan dan kurang memahami soal dengan baik, tidak terbiasa menuliskan apa yang diketahui dan ditanyakan serta tidak memahami apa yang diminta soal.

Item indikator soal kelima adalah menarik kesimpulan logis. Di bawah ini merupakan hasil wawancara peneliti (P) dengan MT.

$\mathrm{P} \quad$ : "Dari nomor 5 informasi apa saja yang anda dapatkan?"

MT : "Informasi yang saya dapatkan yaitu, yang mendapatkan diskon pada hari Sabtu sebesar 30\% yaitu untuk harga diatas 300.000, lalu pada hari Minggu diskon ditambah 20\% untuk barang diatas 599.000, Ibu Yani membeli barabf 400.000 pada hari Sabtu berarti ibu Yani mendapatkan diskon 30\%, lalu pada hari Minggu ibu Yani belanja 999.000 sehingga sesuai ketentuan apabila diskon dijumlahkan maka mendapatkan diskon 50\%, dan ibu Yani membeli lagi dengan seharga 596.000 karena tidak memenuhi persyaratan untuk mendapatkan diskon, maka harga tetap"

P : : "Apa yang ditanya dalan masalah ini?"

MT : "Selisih harga pada hari Minggu dan Sabtu"

P : : "Dapatkah anda menjelaskan langkah-langkah dalam menyelesaian masalah ini?"

MT : "Langkah pertama yang saya lakukan yaitu mencari harga yag mendapatkan diskon 30\% sehingga mendapatkan 120.000, lalu dikurangkan dengan harga awal 400.000, sehingga $400.000-120.000=270.000$, lalu mencari harga mendapatkan diskon 50\% sehingga didapat 499.500, lalu dikurangkan dengan harga awal 999.000, sehingga $999.000-499.500=399.500$, lalu ditambahkan dengan belanjaan ke 2 yaitu 596.000 sehingga $399.500+596.000=995.500$, sehingga selisish belanjaan pada hari Minggu dan sabtu adalah 725.500, sehingga selisih ketentuan pada soal salah"

P : "Menurut kamu apakah langkah yang kamu gunakan sudah benar?"

MT : "Tya bu"

P : :Kesulitan apa yang kamu hadapi dalam menyelesaikan masalah ini?”

MT : "Kesulitan nya dalam menentukan harga diskon pada hari Minggu"

P : : "Kesimpulan apa yang anda peroleh dari masalah ini?"

MT : "Kesimpulannya, selisih pada soal tidak sama dengan selisih yang saya peroleh."

Berdasarkan hasil wawancara MT yakin dengan langkah yang dikerjakan. MT mampu dalam memahami dan menjelaskan cara penyelesaiannya, artinya MT 
mampu dalam indikator menarik kesimpulan logis. Gambar 6 merupakan hasil solusi atau penyelesaian pada siswa MT dalam menyelesaikan soal HOTS.

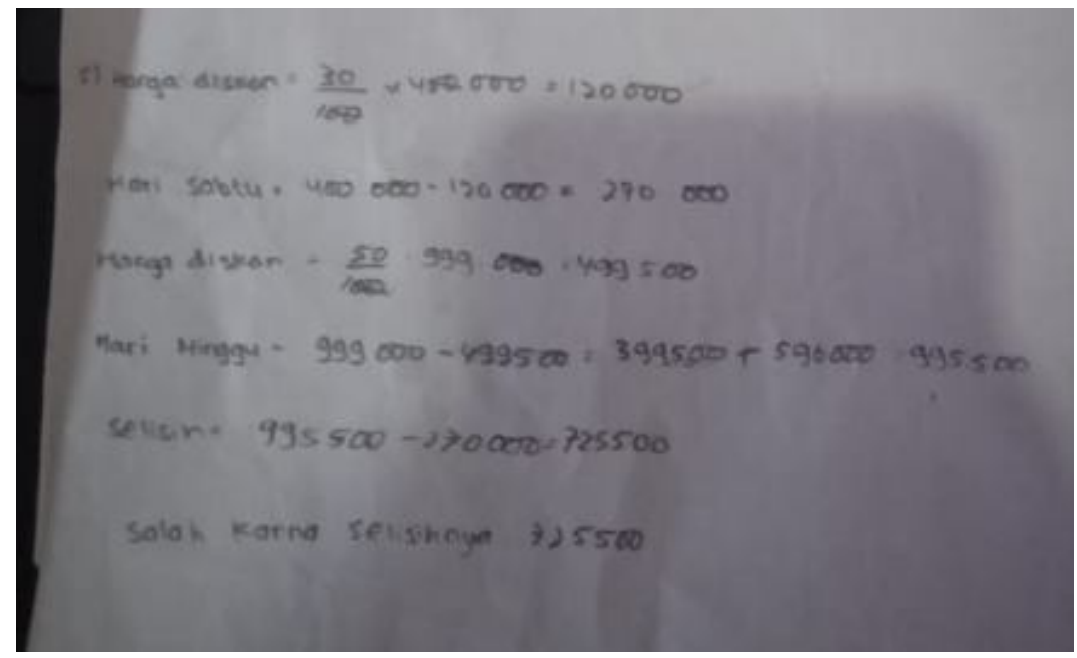

Gambar 6. Kesalahan Keterampilan Proses pada Indikator Kelima

Berdasarkan hasil jawaban MT dan wawancara, MT tidak mampu menyelesaikan soal HOTS indikator kelima. MT mampu dalam membaca informasi soal yang diberikan dan memahami apa yang ditanyakan serta yang diketahui, namun MT salah dalam komputasi. Terlihat dalam gambar 6 bahwa $400.000-120.000$ menghasilkan 270.000, seharusnya adalah 280.000. Sehingga MT melakukan kesalahan dalam menyelesaikan soal HOTS, namun kemampuan penalaran matematis siswa MT dalam menarik kesimpulan logis sangat baik dengan memberikan pernyataan bahwa itu adalah salah. Hasil perhitungan MT juga masih kurang tepat, sehingga MT pada indikator kelima memiliki kesalahan dalam keterampilan proses. Hasil penelitian Gaiz \& Afriansyah (2017) juga menyatakan faktor penyebab kesalahan siswa dalam menyelesaikan soal HOTS diantaranya siswa kurang teliti dalam proses pengerjaan.

\section{Paparan Hasil Analisis Kesalahan Siswa yang mempunyai Kemampuan Pena- laran Rendah (SKPR)}

Kemampuan penalaran matematis rendah siswa dalam menyelesaikan soal HOTS dipilih random dari siswa yang memiliki kemampuan penalaran rendah yaitu kode 12 (FC). Berdasarkan hasil jawaban yang dikerjakan oleh FC, FC tidak mampu dalam menyelesaikan semua item soal kecuali item indikator kelima yaitu menarik kesimpulan logis. 
Item Indikator soal pertama, kedua, ketiga dan keempat siswa FC tidak mengetahui cara menyelesaikannya bahkan tidak memahami maksud apa yang ditanyakan soal. Di bawah ini merupakan hasil wawancara Peneliti (P) dengan FC.

$\mathrm{P} \quad$ : “Kenapa kamu hanya mengerjakan soal no 5?”

FC : "Iya bu hanya mengerjakan soal no. 5"

$\mathrm{P} \quad$ : " Kesulitan apa yang kamu hadapi di soal No.1,2,3 dan 4?"

FC : "Untuk no. 1 kesulitannya kurang bisa memahami soal, bingung memaknai maksud dari soal, begitupun soal no. 2, 3, dan 4 bu"

P : : "Menurut kamu dari kelima soal tersebut mana yang menurut kamu paling sulit?"

FC : "No.4 bu, sama seperti no.1 kurang bisa memahami soal, bingung memaknai maksud dari soal, bingung maksud gambar pada soal"

P : : "Lalu no.5 kamu bisa menjawabnya?"

FC : "Tya bu"

$\mathrm{P} \quad$ : “Informasi apa yang kamu peroleh dari soal no.5?"

FC : "Informasi yang saya dapatkan adalah harga pada hari Sabtu dan Minggu, diskon yang terdapat pada kedua hari tersebut dan, selisih harga pada soal"

$\mathrm{P} \quad$ : "Apa yang ditanya dalan masalah ini?"

FC : "Apakah benar selisih harga yang ditemukan bu Yani"

P : :Dapatkah anda menjelaskan langkah-langkah dalam menyelesaian masalah ini?"

FC : "Langkah pertama yang saya lakukan yaitu mencari harga pada hari sabtu dan dikalikan dengan 30\% sehingga mendapatkan 120.000, lalu dikurangkan dengan harga awal 400.000, sehingga $400.000-120.000=280.000$, lalu mencari harga pada hari minggu dan dikalikan dengan 20\% sehingga didapat 199.800, lalu dikurangkan dengan harga awal 999.000, sehingga $999.000-199.800=799.200$, lalu ditambahkan dengan belanjaan ke 2 yaitu 596.000 sehingga $799.200+$ $596.000=1.395 .000$, sehingga selisish belanjaan pada hari Minggu dan sabtu adalah $1.395 .000-280.000=1.115 .000 "$

$\mathrm{P} \quad$ : "Menurut kamu apakah langkah yang kamu gunakan sudah benar?"

FC : "Ya bu"

$\mathrm{P} \quad$ : “Kesulitan apa yang kamu hadapi dalam menyelesaikan masalah ini?”

FC : "Kesulitan nya adalah angkanya membuat saya rumit, dan menentukan diskonnya"

P : : "Kesimpulan apa yang anda peroleh dari masalah ini"

FC : "Kesimpulannya, saya bisa menentukan selisih harga pada hari Sabtu dan Ming$\mathrm{gu}^{\prime \prime}$

Berdasarkan hasil wawancara bahwa FC tidak mampu dalam indikator soal 1-4, FC hanya mampu dalam indikator menarik kesimpulan logis dengan kesalahan komputasi/ perhitungan. Berdasarkan hasil wawancara dan lembar jawaban FC maka dapat kesalahan siswa FC dalam menyelesaikan soal HOTS berdasarkan kemampuan pe- 
nalaran adalah kesalahan dalam memahami soal HOTS pada keempat indikator, sehingga FC tidak menjawab dalam lembar jawaban. FC hanya mampu menjawab indikator nomor lima yaitu menarik kesimpulan logis. Gambar 7 merupakan hasil solusi atau peyelesaian pada siswa FC dalam menyelesaikan soal HOTS.

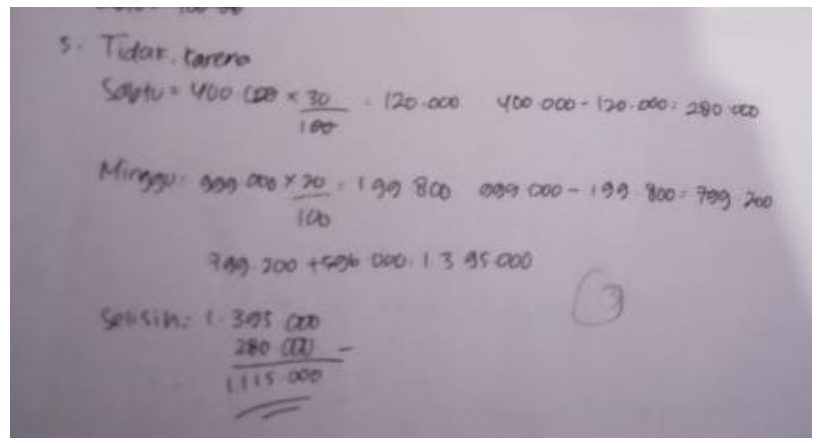

Gambar 7. Kesalahan Keterampilan Proses pada Indikator Kelima

Berdasarkan hasil wawancara dan lembar jawaban FC mampu membaca informasi soal dengan baik dan memahami apa yang ditanyakan dan diketahui dalam soal HOTS. Untuk hasil perhitungan, FC salah dalam melakukan komputasi. Berdasarkan gambar 7, untuk perhitungan hari Sabtu FC melakukan komputasi dengan baik. Namun untuk hari minggu salah dalam menghitung hasil pengurangan. Hal ini menyebabkan FC salah dalam mendapatkan hasil jawaban akhir, sehingga menyebabkan FC salah dalam perhitungan. Kemampuan FC hanya sampai keterampilan proses. Faktor penyebab kesalahan siswa menurut penelitian Mahmudah (2018) yaitu kemampuan penalaran dan kreativitas siswa yang rendah.

\section{Kesimpulan}

Subjek dengan kemampuan penalaran yang tinggi yaitu MT mampu memahami dan menyelesaikan soal HOTS dengan baik. Berbeda dengan subjek dengan kemampuan penalaran rendah yaitu FC yang tidak memahami dengan baik soal HOTS dan menyebabkan kemampuan kognitifnya sangat rendah dalam menyelesaikan soal HOTS. Baik siswa yang memiliki kemampuan penalaran tinggi (SKPT) dengan kode 21 (MT) dan siswa yang memiliki kemampuan rendah (SKPR) dengan kode 12 (FC) memiliki kesalahan yang sama pada indikator kemampuan menarik kesimpulan logis yaitu kesalahan pada keterampilan proses yaitu salah dalam melakukan perhitungan atau komputasi. Pada indikator justifikasi atau pembuktian baik SKPT dan SKPR memiliki kesalahan yang sama yaitu kesalahan dalam memahami soal, artinya soal HOTS tidak dipahami dengan baik oleh SKPT dan SKPR. 
Perbedaan kesalahan siswa dalam menyelesaikan soal HOTS pada SKPT dan SKPR terletak pada indikator menggunakan pola dan hubungan untuk menganalisis situasi matematika, menarik anologi dan generalisasi dimana SKPT mampu menyelesaikan soal HOTS tanpa kesalahan apapun sehingga SKPT mampu menjawab dengan benar, sedangkan kesalahan SKPR adalah kesalahan memahami soal sehingga SKPR sulit untuk menyelesaikannya, perbedaan yang lain terletak pada indikator memberikan penjelasan dengan menggunakan model, fakta, sifat dan hubungan dan indikator memperkirakan jawaban dan proses solusi dimana SKPT memiliki kesalahan sangat rendah dibandingkan dengan SKPR, yaitu kesalahan dalam keterampilan proses yaitu kesalahan melakukan perhitungan dalam menyelesaikan soal HOTS, sedangkan SKPR terletak pada kesalahan memahami soal.

\section{Daftar Pustaka}

Abosalem, Y. (2016). Assessment Techniques and Students' Higher-Order Thinking Skills. International Journal of Secondary Education, 4(1), 1-11. https:// doi.org/ 10.11648/j.ijsedu.20160401.11

Agustina, L. R., \& Khotimah, R. P. (2018). Kesalahan Dalam Menyelesaikan Soal Bentuk Aljabar Tipe Higher Order Thinking Skills ( Hots ).

Aliyanti, A. P., Putri, O. R. U., \& Zukhrufurrohmah, Z. (2019). Analisis Kesalahan Representasi Simbolik Mahasiswa Dalam Menyelesaikan Soal High Order Thinking Skill. AKSIOMA: Jurnal Program Studi Pendidikan Matematika, 8(3), 382. https:/ / doi.org/ 10.24127/ ajpm.v8i3.2265

Barak, M., Ben-Chaim, D., \& Uri, Z. (2007). Purposely Teaching for the Promotion of Higher-order Thinking Skills : A case of Critical Thinking. Research in Science Education Vol 37 No.4,353-369

Conklin, W. (2012). Higher-Order Thinking Skills to Develop 21st Century Learners.Huntington Beach: Shell Educational Publishing, Inc.

Gais, Z., \& Afriansyah, E. A. (2017). Analisis Kemampuan Siswa dalam Menyelesaikan Soal High Order Thinking Ditinjau dari Kemampuan Awal Matematis Siswa. Mosharafa :Jurnal Pendidikan Matematika, 6(2), 255-266.

Hadi, W. (2016). Meningkatkan Kemampuan Penalaran Siswa SMP melalui Pembelajaran Discovery dengan Pendekatan Saintifik (Studi Kuasi Eksperimen di Salah Satu SMP Jajakrta Barat). Kalamatika : Jurnal Pendidikan Matematika, 93-108.

Hassan, S. R., Rosli, R., \& Zakaria, E. (2016). The Use of i-Think Map and Questioning to Promote Higher-Order Thinking Skills in Mathematics. Creative Educa- 
tion, 7, 1069-1078. doi:http:// dx.doi.org/ 10.4236/ ce.2016.77111

Jailani, J., Sugiman, S., \& Apino, E. (2017). Implementing the problem-based learning in order to improve the students' HOTS and characters. Jurnal Riset Pendidikan Matematika, 4(2), 247. https:/ / doi.org/ 10.21831/jrpm.v4i2.17674

Johar, R., Yusniarti, S., \& Saminan. (2018). The analysis of proportional reasoning problem in the Indonesian mathematics textbook for the junior high school. Journal on Mathematics Education, 9(1), 55-68. https:/ / doi.org/ 10.22342/ jme.9.1.4145.55-68

Kurnia, L., \& Yuspriyati, D. N. (2020). Analisis Kesulitan Siswa SMP dalam menyelesaikan soal Aritmatika Sosial Berdasarkan Analisis Newman. Mathematic Paedagogic, IV(2), 116-119.

Mahmudah, Wilda. (2018). Analisis Kesalahan dalam Menyelesaikan Soal Matematika Bertipe Hots Berdasar Teori Newman. Jurnal UJMC, 4(1), 49-56.

Mu'minah, K. I. (2018). Kesalahan Siswa Dalam Menyelesaikan Soal Matematika Tipe Higher Order Thinking Skill ( Hots ) Pada Pokok Bahasan Aritmatika Sosial. 2-11.

Mulyani, M., \& Muhtadi, D. (2019). Analisis Kesalahan Siswa Dalam Menyelesaikan Soal Trigonometri Tipe Higher Order Thinking Skill Ditinjau Dari Gender. Jurnal Penelitian Dan Pembelajaran Matematika, 12(1), 1-16. https:// doi.org/ 10.30870/jppm.v12i1.4851

Munzenmaier, C., \& Rubin, N. (2013). Perspectives Bloom's Taxonomy : What's Old is New Again. Santa Rosa: The eLearning Guild.

Newman, M. A. (1977) An analysis of sixthgrade pupils' errors on written mathematical tasks. In White, AL (2009) Diagnostic and Pedagogical Issues with Mathematical Word Problems. Brunei International Journal of Scienceand Mathematics Education 1(1) pp 100-112

Nurina, D. L., \& Retnawati, H. (2015). Keefektifan Pembelajaran Menggunakan Pendekatan Problem Posing dan Pendekatan Open-Ended Ditinjau Dari HOTS. PYTHAGORAS: Jurnal Pendidikan Matematika, 10(2), 129. https:// doi.org/ 10.21831/ pg.v10i2.9128

Oktaviana, D. (2018). Analisis Tipe Kesalahan Berdasarkan Teori Newman Dalam Menyelesaikan Soal Cerita Pada Mata Kuliah Matematika Diskrit. Edu Sains: Jurnal Pendidikan Sains \& Matematika, 5(2), 22.

Permana, N. N. (2019). Analisis Kesalahan Siswa dalam Menyelesaikan Soal Higher Order Thinking Skills ( HOTS ) Matematika. Diskusi Panel Nasional Pendidikan Matematika, 19-24. 
Ramos, J. L. S., Dolipas, B. B., \& Villamor, B. B. (2013). Higher Order Thinking Skills and Academic Performance in Physics of College Students: A Regression Analysis. International Journal of Innovative Interdisciplinary Research, (4), 48-60. https:/ / doi.org/ ISSN 1839-9053

Rizqi, N. R., \& Surya, E. (2017). An Analysis of Students' Mathematical Reasoning Ability in VIII Grade of Sabilina Tembung Junior High School. Ijariie, 3(2), 3527-3533.

Rohmah, M., \& Sutiarso, S. (2018). Analysis problem solving in mathematical using theory Newman. Eurasia Journal of Mathematics, Science and Technology Education, 14(2), 671-681. https:// doi.org/ 10.12973/ ejmste/ 80630

Tanujaya, B., Mumu, J., \& Margono, G. (2017). The Relationship Between Higher Order Thinking Skills and Academic Performance of Student in Mathematics Instruction. International Eeducation Studies Volume 10 Nomor 11, 78-85.

Wang, S., \& Wang, H. (2011, April 21). Teaching Higher Order Thinking in the Introductory MIS Course : A Model Directed Approach. Journal of Education for Business, 86(4), 208-213. doi:https:/ / doi.org/ 10.1080/ 08832323.2010.505254

Wibowo, Pamujiarso H.E. \& Rini S. (2016). Pemberian Scaffolding Untuk Meningkatkan Keterampilan Berpikir Tingkat Tinggi (Higher Order Thinking Skills) Kelas X SMA Berdasarkan Kemampuan Matematika Siswa. MATHEdunesa Jurnal Ilmiah Pendidikan Matematika, 2(5), 7380.

Yang, Y. T. C. (2015). Virtual CEOs: A blended approach to digital gaming for enhancing higher order thinking and academic achievement among vocational high school students. Computers and Education, 81, 281-295. https:// doi.org/ 10.1016/ j.compedu.2014.10.004 